\title{
SSR BACKGROUNDER
}

\section{Defence Reform}

Applying the principles of good security sector governance to defence

\begin{abstract}
About this series
The SSR Backgrounders provide concise introductions to topics in good security sector governance (SSG) and security sector reform (SSR). The series summarizes current debates, explains key terms and exposes central tensions based on a broad range of international experiences. The SSR Backgrounders do not promote specific models, policies or proposals for good governance or reform but do provide further resources that will allow readers to extend their knowledge on each topic. The SSR Backgrounders are a resource for security governance and reform stakeholders seeking to understand and to critically assess current approaches to good SSG and SSR.
\end{abstract}

\section{About this SSR Backgrounder}

This SSR Backgrounder is about applying the principles of good security sector governance (SSG) to defence through defence reform. The military is concerned with the defence of a state and its people. By increasing democratic oversight and control, defence reform ensures that military power is used according to the will and in defence of the population. Defence reform enables the military to fulfil its mandate more efficiently and effectively, in order to function flexibly in a dynamic security environment.

\section{This SSR Backgrounder answers the following questions:}

What is defence reform? Page 2

Why reform defence? Page 4

Who carries out defence reform? Page 5

How does a defence reform process work? Page 6

What links defence reform to good SSG and SSR? Page 7

- How to overcome barriers to defence reform? Page 8 


\section{What is defence reform?}

Defence reform in the context of SSR enhances democratic control and oversight over the military and the defence sector, making both more effective, accountable and affordable. (For more on democratic control of the armed forces, see the SSR Backgrounders on "Security Sector Governance" and "The Armed Forces").

Defence reform must consider the government, the army and the people. Better behaviour and cultural change can improve the relationship between security forces and the population they protect. At the same time, the army must be responsive to the government's policies and has to maintain its effectiveness. Responsive and democratic SSG ensures the government's defence policies reflect the will of the people.

In reshaping these relationships, defence reform will:

- Assess the strategic environment in order to identify the threats, risks and challenges facing a country over the short to long term;

\section{- Review operational roles and objectives} of the armed forces and civilian defence sector institutions;

- Reconsider relationships between the defence sector and other security providers, as well as the institutions of defence oversight and management;

- Budget for priorities, action plans and reform programmes for armed forces and defence institutions.
The armed forces and the defence sector

The defence sector is the domain of public administration responsible for military power. Usually it comprises the armed forces, their political leadership (commander in chief, ministry of defence), the executive controlling authorities (president, prime minister) and other state agencies permanently or occasionally involved in defence matters. In some cases, the defence sector also includes commercial service providers within the defence industry.

The defence sector typically has three roles:

1. Operational conduct, i.e. command and execution of military operations;

2. Human resources management, i.e. recruitment, training and administration of personnel, as well as operational planning;

3. Financial and technical management, i.e. budgeting, financial management, procurement of military equipment and provision of technical advice to the government.

The armed forces are institutions established by the state for the primary purpose of national defence against external threats. They might also have delegated authority to respond to domestic conflict and natural disasters. They may include regular, auxiliary and/or reserve military forces. For more on the roles and responsibilities of the armed forces in good SSG, see the SSR Backgrounder "The Armed Forces". 
Once plans have been made, defence reform activities can be technical or administrative, and may span several areas, for example:

- Military doctrine, rules of engagement and operating procedures;

- Weapons systems, logistics and defence infrastructure;

- Force size and structure;

- Management and budget systems;

- Personnel policies (professionalization, recruitment, training, promotion, retirement and the representativeness of a country's defence establishment);

- Relationships among the services (sometimes called "jointness") and with other parts of the security sector both at home and abroad (sometimes called "interoperability");

- Communications policy for members of the forces, the media and the public;

- Democratic civil-military relations;

- Respect for the rule of law and human rights both within the military and in their operations.
Good security sector governance (SSG) and security sector reform (SSR) Good SSG describes how the principles of good governance apply to public security provision, management and oversight. The principles of good SSG are accountability, transparency, the rule of law, participation, responsiveness, effectiveness and efficiency.

The security sector is not just security providers: it includes all the institutions and personnel responsible for security management and oversight at both national and local levels.

Establishing good SSG is the goal of security sector reform. SSR is the political and technical process of improving state and human security by making security provision, management and oversight more effective and more accountable, within a framework of democratic civilian control, the rule of law and respect for human rights. SSR may focus on only one part of public security provision or the way the entire system functions, as long as the goal is always to improve both effectiveness and accountability.

For more information on these core definitions, please refer to the SSR Backgrounders on "Security Sector Governance", "Security Sector Reform" and "The Security Sector". 


\section{Why reform defence?}

Defence reform has two interrelated aims: to enhance the performance of the defence sector in fulfilling its three main roles (see box above) and to ensure high standards of integrity within a framework of democratic governance, the rule of law and respect for human rights. Increasing the effectiveness and efficiency of the armed forces is only desirable when the government, parliament and the public can hold security actors accountable. Greater inclusiveness, responsiveness, transparency and accountability improve the legitimacy and credibility of the armed forces and the defence sector as a whole in the eyes of the public they serve. Strengthening democratic civilian control, the rule of law and respect for human rights thus helps the armed forces and the defence sector better perform their mission of protecting the state and its people.

The priorities of defence reform vary according to the political context of each country:

- In consolidated democracies, defence reform is usually an ongoing process to improve the accountability, effectiveness and affordability of existing military and defence institutions.

- In countries undergoing political transition, defence reform usually focuses on more effective national defence within a more democratic system of oversight and control.

- In conflict-affected countries, defence reform aims to improve national stability while preventing or responding to violence; the means to achieve this focus on more democratic SSG, reconciliation measures and greater inclusiveness.

\section{Defence reform in post-conflict situations}

Nations emerging from conflict face specific challenges in defence reform, for example:

- Demilitarizing society and armed groups;

- Managing stockpiles and destroying surplus;

- Establishing new national armed forces;

- Integrating ex-combatants from all conflict parties into security services;

- Dealing with war crimes and other major human rights violations;

- Addressing the legacy of fear and distrust of the armed forces, including ending impunity and adopting a zero-tolerance policy towards misbehaviour;

- Fighting conflict-era legacies of defence sector corruption. 


\section{Who carries out defence reform?}

Civilian ministries (or departments) of defence are best placed to carry out defence reforms. The ministry must have appropriate civilian and military expertise to manage a complex process. A comprehensive process will consider both national and international actors, as well as both public and private institutions with a role in the defence sector (see figure 1).

\section{Figure 1 Defence reform involves a wide range of actors across the security sector and society}

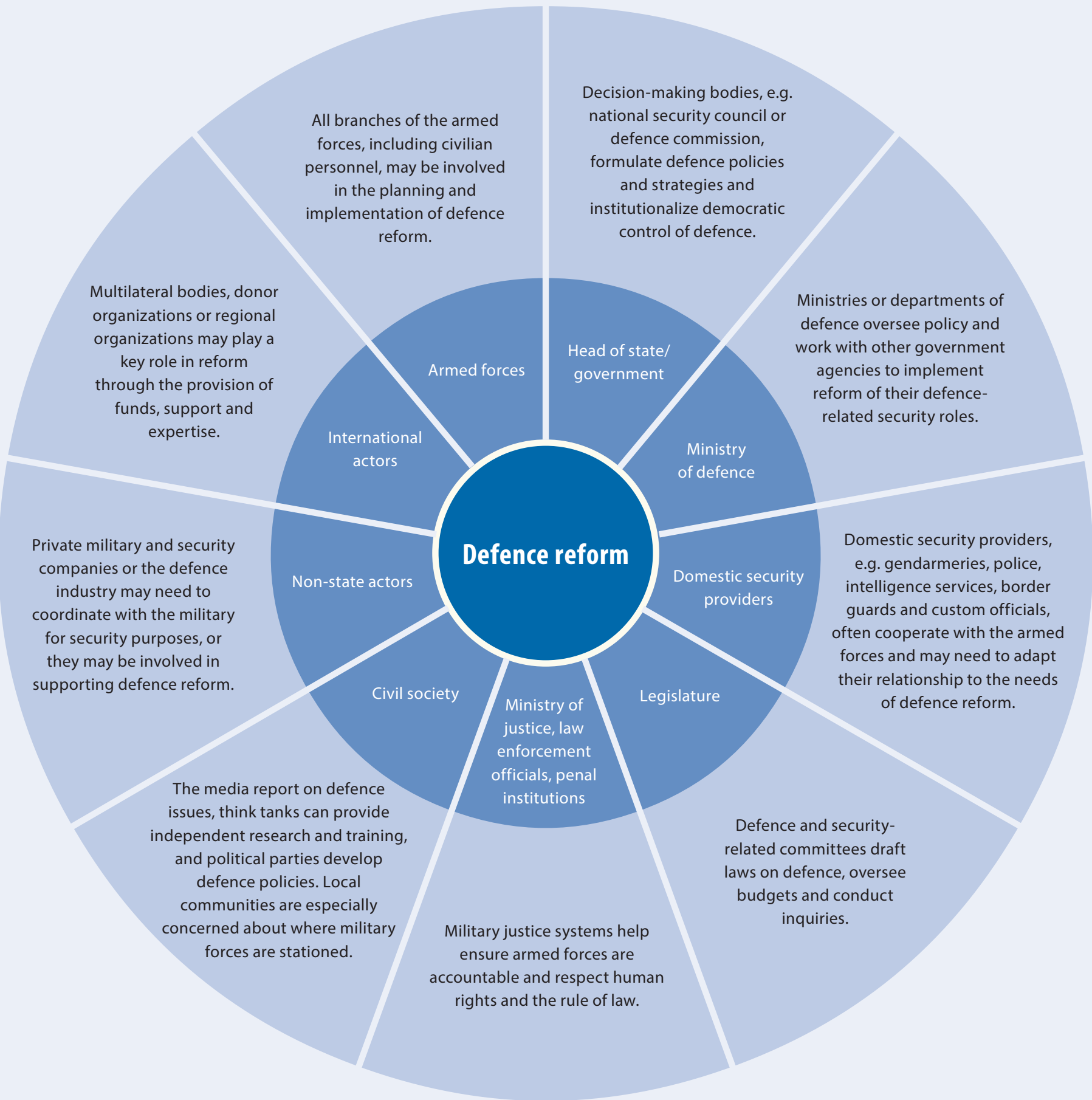




\section{How does a defence reform process work?}

A public consultation on the role of the armed forces and the state's defence needs can be a good starting point for adapting defence reform to the political, economic and social context. After that, typical elements of defence reform include:

- Conducting a defence review. A defence review asks what role defence is to serve, analyses the security environment and its threats, and includes a public consultation and information process. The law may require a country to conduct regular comprehensive defence reviews but many countries do so only when circumstances dictate. A defence review can be part of broader security review processes, and or a major defence transformation, but not all defence reform processes need to be preceded by a review.

- Design, planning and consultation. Defence reform is planned by military and civilian personnel in permanent structures or in ad hoc committees and special commissions to ensure that the available means are appropriate to reach the desired ends and within a set budget. A wide range of stakeholders from both within and outside the defence sector should be consulted, especially on decisions that affect communities.

- Implementation, monitoring and adjustment. Effective defence reform requires mechanisms to monitor implementation and outcomes of reform, so that programmes can be adjusted in light of progress and changes to the environment. This is especially important considering that comprehensive reform programmes often last longer than the term of office of the government that initiated them.

Careful financial planning and management is essential because defence reform can be costly - particularly if it requires a country to invest in new military capabilities. Cost analysis, monitoring and budgetary follow-up throughout the process provide stability and sustainability.
The advantages of achieving gender equality in the defence sector Gender equality improves the performance of the security sector while enhancing fundamental human rights and democratic fairness (see the SSR Backgrounders on "Gender Equality and Good Security Sector Governance" and "Gender Equality and Security Sector Reform"):

- Better performance: Gender equality has tactical advantages - being able to operate with all genders in a particular society; operational advantages - being able to conduct gendered analysis of the operating environment; and strategic advantages - full diversity in decisionmaking improves quality.

- Defending rights and integrity: Gender equality is integral to principles of democratic civilian control, the rule of law and respect for human rights. Equal access to provision, management and oversight of security, as well as responsiveness to gender-specific security needs, are all important benchmarks for measuring norm compliance in the defence sector.

A sustained public information effort helps the defence establishment as well as the population to understand and critically assess reform. Information campaigns should cover the short- and long-term benefits of comprehensive defence reform weighed against the short-term human and social consequences, as well as pressures to address perceived immediate threats.

Given the expense and long lifespan of military hardware, many countries put in place a defence planning system. For example, a plan may combine a long-term perspective (15 to 20 years, for example) with one that is much more specific and detailed (four years, for example). Defence reform needs to account for past decisions but also to anticipate future developments in security, technology and demography, as well as changes in society's views of itself. 


\section{What links defence reform to good SSG and SSR?}

Reform attempts that focus solely on technical elements of performance, training or equipment, without regard for accountability and democratic control, are not part of SSR and can undermine good SSG. Accountability applies internally and externally to defence sector institutions and the armed forces through command and control, as well as to the work of the ministry of defence.

Examples of outputs and outcomes of defence reform that improve accountability and transparency of the defence sector include:

\section{- New oversight institutions or processes,} for example, an integrated ministry of defence combining civilian and military headquarters, a military ombuds person or a parliamentary defence or security committee;

- Changes to the military chain of command, enhanced constitutional controls and strengthened civil society monitoring of the military;

\section{- Deeper knowledge of the defence sector,} for example, through new curricula for defence education and public information about the roles and obligations of the armed forces.
Mechanisms linking internal and external oversight can also increase accountability of the security services overall, for example:

- Separation of powers: Police, border authorities and other security services must be clearly delineated from the military. Adequate legal frameworks and mandates ensure that there are no security gaps or overlaps of mission or responsibility.

- Quality leadership: Internal codes of conduct, administrative discipline and cultural aspects, including a sense of duty and responsibility, also maintain integrity within the military.

- Justice mechanisms: Civilian and military justice systems are last-resort instruments that guarantee that the military operates with integrity. Where a functioning judicial system exists, military personnel are usually placed under special judicial procedures whereas civilians are tried by civilian courts.

- Civilian oversight: Competent parliamentary institutions, as well as courts of auditors, the media and civil society organizations, provide democratic defence oversight. 


\section{How to overcome barriers to defence reform?}

Every country faces challenges when undertaking defence reform but applying the principles of good SSG through SSR can help address these problems. For example:

Political and institutional resistance: The government and/or certain military institutions may resist change because they have a vested interest in the status quo, a differing threat perception, a sense of tradition or fear of loss of power and control. The trust and cooperation necessary for reform may be absent in conflict-affected contexts.

- Context analysis, a conflict-sensitive approach, mobilizing international and/or public support for reform, and raising awareness about the benefits of good SSG among stakeholders, can help overcome political resistance (see the SSR Backgrounder "Security Sector

Governance").

Technical challenges: Defence reform planning and management is complex and requires both the participation of military and civilian defence experts and civil society participation and public consultation. Insufficient financial resources also hamper reform.

- Diverse decision-making and expertise, capacitybuilding and external support can provide the required expertise and financial resources. Setting defence reform in the context of a broader SSR programme can help (see the SSR Backgrounder "Security Sector Reform").

Uncertainty: The potential benefits of defence reform can be hard to measure and that makes reform seem risky or unimportant in the eyes of politicians and the public. People also fear change, including the possibility that the country may appear to be more vulnerable during reform.

- Public outreach and professional education about the benefits of reform can help overcome fear, especially in the context of a review of national security policy (see the SSR

Backgrounder "National Security Policies"). 


\section{What to read next}

For a comprehensive set of online resources on defence reform, visit

http://issat.dcaf.ch/Learn/SSR-in-Practice/Thematicsin-Practice/Defence-Reform

For an overview of international policy standards of defence reform:

- United Nations Department of Peacekeeping Operations

Policy: Defence Sector Reform

New York: United Nations, 2011.

- OECD Development Assistance Committee Section 7.2: Defence Reform

in OECD DAC Handbook on Security System Reform:

Supporting Security and Justice, 124-139.

Paris: Organisation for Economic Cooperation and

Development, 2007.

For further details on defence management and institution building:

- Hari Bucur-Marcu (ed.)

Essentials of Defence Institution Building

Vienna, Geneva: DCAF, 2009.

- Hari Bucur-Marcu, Philipp Fluri and Todor Tagarev (eds.)

Defence Management: An Introduction

Geneva: DCAF, 2009.

- Willem Frederik van Eekelen and Philipp Fluri (eds.) Defence Institution Building: A Sourcebook in Support of the Partnership Action Plan Vienna: Austrian National Defence Academy, 2006.

For further information on defence reform in post-conflict situations:

- Mark Knight

SSR: Post-conflict Integration

Helpdesk Query. Birmingham: University of

Birmingham, Global Facilitation Network for Security

Sector Reform, August 2009.
- Roy Licklider (ed.)

New Armies from Old: Merging Competing Military Forces after Civil Wars Washington, DC: Georgetown University Press, 2014.

- Alexandra Kerr and Michael Miklaucic (eds.) Effective, Legitimate, Secure: Insights for Defence Institution Building

Washington, DC: National Defense University, Center for Complex Operations, 2017.

For further details on democratic control and oversight in defence reform:

- Valeri Ratchev

Civilianisation of the Defence Ministry:

A Functional Approach to a Modern Defence Institution

Geneva: DCAF, 2011.

- Benjamin S. Buckland and William McDermott Ombuds Institutions for the Armed Forces:

A Handbook

Geneva: DCAF, 2012.

- Todor Tagarev (ed.)

Building Integrity and Reducing Corruption in Defence: A Compendium of Best Practices Geneva: DCAF, 2010.

- Cheryl Hendricks and Lauren Hutton Tool 3: Defence Reform and Gender

in Gender and Security Sector Reform Toolkit, edited by Megan Bastick and Kristin Valasek. Geneva: DCAF, OSCE/ODIHR, UN-INSTRAW, 2008.

\section{More DCAF resources}

- DCAF publishes a wide variety of tools, handbooks and guidance on all aspects of SSR and good SSG, available free-for-download at www.dcaf.ch or https://securitysectorintegrity.com/ defence-management

Many resources are also available in languages other than English.

- The DCAF-ISSAT website makes available a range of online learning resources for SSR practitioners at http://issat.dcaf.ch 


\section{DCAF, the Geneva Centre for Security Sector}

Governance, is an international foundation whose mission is to assist the international community in pursuing good governance and reform of the security sector. DCAF develops and promotes norms and standards, conducts tailored policy research, identifies good practices and recommendations to promote democratic security sector governance and provides in-country advisory support and practical assistance programmes.

DCAF wishes to thank

Thammy Evans for authorship;

Ronja Harder and Jasper Linke for contributions to research, writing and editing; Jenny Rouse for copy editing in English; Florence Lesur for translation into French; Géraldine Chantegrel for copy editing in French; and Petra Gurtner for layout and design.

Series editor

Fairlie Chappuis

To cite this publication

DCAF - Geneva Centre for Security Sector Governance. Defence Reform. SSR Backgrounder Series. Geneva: DCAF, 2019.

(c) DCAF. SSR Backgrounders are available free of charge from www.dcaf.ch. Users may copy and distribute this material provided that DCAF is credited.

Not for commercial use. 
Notes 


\section{$D C \wedge F^{\text {Gomosectate }}$ for Security Sector \\ Governance}

DCAF - Geneva Centre for Security Sector Governance P. O. Box 1360

$\mathrm{CH}-1211$ Geneva 1

Switzerland

\section{Download DCAF's SSR Backgrounders App}

A comprehensive resource on the fundamentals of good security sector governance and reform including:

SSR Backgrounders: short introductions to key topics in security sector governance and reform.

SSR Papers: cutting edge analysis of the latest trends in security sector governance, written, reviewed and edited by reform specialists.

DCAF Resources: a selection of our best practical guidance for reform practitioners including handbooks, toolkits and guidance notes in a wide range of languages.

The app offers:

- one-time download resources for full offline access

- a choice of two reading modes for clearer text and better zooming

- optimized iOS and Android formats that perform fast but are light on data and storage 